\title{
A keyword on the footer: the Furtadian and the (re)current meaning of structural reforms
}

\author{
Uma palavra-chave nas notas de rodapé: o significado furtadiano \\ e o (re)corrente de reformas estruturais
}

GUILHERME SILVA CARDOSO*

\begin{abstract}
RESUMO: Uma mudança semântica ocorreu no escopo do termo reformas estruturais. Este artigo revisa a obra de Celso Furtado, em particular, as relacionadas a esse tema específico, e compara-a com a literatura atual. As reformas estruturais na concepção de Furtado conotavam transformações de base e eram guiadas pela escola de pensamento desenvolvimentista. Hoje, é do conhecimento geral que, sob a influência neoinstitucionalista, as "reformas estruturais" estão associadas a políticas liberais de monitoramento das consolidações fiscais, sem consenso quanto ao poder de eficácia. O esforço para resgatar e compreender as concepções originais de certas palavras-chave na literatura de desenvolvimento econômico, bem como a maneira como suas interpretações e práticas se modificam ao longo do tempo, mostra-se de suma importância na luta do sistema capitalista para encontrar maneiras de se adaptar à situação atual das economias em desenvolvimento.
\end{abstract}

PALAVRAS-CHAVE: Celso Furtado; Reformas Estruturais; Reformas Institucionais; Economias em Desenvolvimento.

ABSTRACT: A semantic change has occurred in the scope of structural reforms' term. This article reviews Celso Furtado's work, in particular, the ones related to this specific topic, and compares it with the current literature. It appears that structural reforms in the Furtadian conception connoted base transformations and were guided by the developmentalism school of thought. Nowadays, it is of general knowledge that, under the new-institutionalist influence, "structural reforms" are associated with liberal policies for monitoring fiscal consolidations, without consensus as to the power of effectiveness. The effort to rescue and understand the original conceptions of certain keywords in the economic development literature, as well as the way in which their interpretations and practices modify over time, is shown to be of paramount importance as the capitalist system struggle to find ways of adapting itself to the current situation of developing economies.

KEYWORDS: Celso Furtado; Structural Reforms; Institutional Reforms; Developing Economies. JEL Classification: O2; O54; P11.

\footnotetext{
* Centro de Desenvolvimento e Planejamento Regional - CEDEPLAR, Universidade Federal de Minas Gerais - UFMG, Belo Horizonte/MG, Brasil. E-mail: guilherme-cardoso@cedeplar.ufmg.br. Orcid: https://orcid.org/0000-0002-0702-8992. Submitted: 9/December/2020; Approved: 20/January/2021.
} 


\section{INTRODUCTION}

One of the thematic areas of the extensive work of Celso Furtado, who would reach 100 years of age in July 2020, makes reference to structural reforms-currently presented in the literature, as well as in the fiscal policy debate, as a character with a supporting role.

However, a change in the connotation of the term attracts attention. Although, in the 1960s, Furtado gave to reforms the responsibility that could once have been among the revolutionary ideals for the solution of Brazilian's structural underdevelopment, as marked by the thoughts of his contemporary, the sociologist Florestan Fernandes ${ }^{1}$, nowadays the theme is associated with fiscal austerity policies as a condition for the return of growth in contexts of recession and economic stagnation.

Based on the maintenance of an accelerated neoliberal agenda in the 1980s in the central economies - more clearly observed in the Latin American economies at the beginning of the 1990s - what was previously incumbent in basic reforms, like the agrarian and urban issue in Brazil as well as the public sector (Furtado, 1962, 1966, 1968), is currently synonymous with privatization, trade opening, and, particularly, flexibilization of the labor market, with the objective of raising the factor productivity in the economy (Anderson et al., 2014; Bardaka et al., 2020).

This article aims to present a keyword from the work of Celso Furtado that has changed completely over the decades and turned into a measure with almost opposite goals to those originally postulated by the author ${ }^{2}$. The changes in international politics, the emergence of new players in the global economy, and internal problems with difficult solutions, such as inflation and indebtedness, certainly influenced the shift in the essence of these ideas, leading us to inquire what remains today of Furtado in the Latin American development ideal-if anything remains at all.

\section{WHAT DOES FURTADO'S BIBLIOGRAPHY}

\section{SAY ABOUT STRUCTURAL REFORMS?}

Firstly, it is worth contextualizing that in the developmentalist tradition, which encompasses the work of Celso Furtado, the reforms were structural because the classical developmental theory defined economic development as a structural change, mainly through a deliberate transfer of the workforce from agriculture to industry. The reforms were structural because they ease the industrialization process and contribute to the reduction of inequality.

From themes such as literature, autobiography, and memory, presented in From Naples to Paris (1946) and Organized Fantasy (1985), to culture, described in Cul-

\footnotetext{
${ }^{1}$ Who would also celebrate his 100th birthday in July 2020.

${ }^{2}$ It is not of importance for this article to investigate the pioneering nature of the term, which, as far as is it concerned, is not attributed to Celso Furtado, but to all the developmentalists of the time.
} 
ture and Development in Times of Crisis (1984) — an area in which he exercised the highest political office in Brazil when he was minister for President José Sarney in the 1980s - the work of Celso Furtado is vast. Looking through the most recognized themes, such as the theory of economic development (The Dialectic of Development, 1964) and the Economic Formation of Brazil (1959), his most acclaimed work, one can consider the theme of structural reforms as a field apart in his work ${ }^{3}$.

Furtado's three main works related to this specific content are:

- The Brazilian Pre-Revolution, from 1962, composed of essays governed by the idea of reforms, especially agrarian and public sector reforms, including the problem of the Northeast region and the creation of Sudene ${ }^{4}$;

- Underdevelopment and Stagnation in Latin America, from 1966, which points out the external and internal obstacles to development, reaching the diagnosis that Brazil is doomed to subordination. When studying the measures of the then Planning Minister Roberto Campos, Furtado warned that, despite the growth, the country was unable to develop since all the growth processes were at the basis of the center-periphery relationship, a certain type of crisis intrinsic to this process;

- A Project for Brazil, from 1968, which contains more optimistic writing despite the context of AI- $5^{5}$. In it, Furtado caught up with the winds of new projects that would undergo development in Brazil.

The fiscal-administrative reform consisted of adapting the state apparatus - the institutions - to meet a repressed social demand in the country. At that time, there was already a diagnosis of tax regression in Brazil, in which the weight of indirect taxes was considerably greater than that of direct taxes.

Furtado postulates the need to "provide the government with a fiscal instrument that enables it to finance its growing investments with resources collected in those sectors that are actually benefiting from development, which is the result of the work of the entire community" (Furtado, 1962, p. 45). The inflation problem, however, persisted in the country's most promising decades and apparently was very similar to the current public debt problem in some economies (Dweck et al., 2018; Nikiforos et al., 2015), as we can see from Furtado's diagnosis in the following passage:

Turning inflation into an autonomous problem is putting our fundamental objective, which is development, in the background. Those who make the problem of inflation an end, are not concerned with development, but with the risks that the social structure and its system

\footnotetext{
${ }^{3}$ All the original versions of these books are cited in the references. Some of them can be found in the English language.

${ }^{4}$ Northeast Development Superintendence, founded by Celso Furtado in 1959, after years of research and political persistence.

${ }^{5}$ Institutional Act No. 5 (AI-5). See D’Araujo (n.d.).
} 
of privileges may take in the face of tensions caused by inflation. We must progressively eliminate inflationary pressure without this having a negative impact on the growth rate. And for that to happen, we must not think exactly in terms of "eliminating" the government deficit, which seems to suppose a necessary contraction in spending. [...] it is necessary to insist on the need for government expenditure to be adequately financed. The fundamental cause of inflation is not an increase in the participation of the public sector in the national product, as this participation is not greater than that of many other countries that enjoy stability [...] what happened was an increasing inadequacy of the fiscal sector to finance public spending. (Furtado, 1962, pp. 45-46. My own translation.)

Agrarian reform was undoubtedly the most emblematic. At the time of the publication of The Brazilian Pre-Revolution, still under the parliamentary regime of João Goulart, it was the issue that scared most Brazilian elites. In addition to reversing the concentrating cycle inherited from pre-capitalist export agriculture (Furtado, 1966, ch. 3), Furtado thought of agrarian reform as a policy for regional development, which, in some regions, should be accompanied by collective forms of appropriation of the soil, such as cooperatives, in the sense of shading the structures of agricultural production in different regions of Brazil (Cano, 2000).

As emphasized by Ferreira and Diniz (1995), in line with Furtado's diagnosis, the convergence of per capita income between Brazilian states in the 1970s and 1980s, the period of greatest effectiveness for industrial decentralization in the country, was associated with the development and expansion of the basic infrastructure; the movement of agricultural and mineral borders; the direct action of the State in terms of investments and the granting of subsidies and tax incentives; crises and reversals of industrial polarization in large urban centers such as Rio de Janeiro and São Paulo; and migratory movements and changes in the regional distribution of the population.

Therefore, the reforms at that time marked a bridge for the implementation of developmentalism in the country in the sense of strictly "economic policy formulated and/or executed, deliberately, by governments (national or subnational) for, through the growth of production and productivity, under the leadership of the industrial sector, transforming society with a view to achieving desirable ends, notably overcoming its economic and social problems, within the institutional frameworks of the capitalist system" (Fonseca, 2013, p. 28).

It is worth mentioning that it is precisely in The Brazilian Pre-Revolution that Furtado defends more emphatically that revolutions, properly speaking, in the light of the socialist experiences of the 20th century, which, although initially auspicious, as in the case of the USSR, always resulted in some kind of oppression and authoritarianism. The reforms, on the other hand, would bring new centralities and new steps toward collective enrichment, overcoming any possibility of authoritarianism 
"from top to bottom"; that is, they would lead to a free, democratic, and egalitarian society that universalizes fundamental rights and values emancipatory possibilities.

Agrarian reform would contribute to the distribution of land and primary income and would be the driving force in the process of reversing the center-periphery status of the international division of labor that, linked to industrialization, would provide what was marked by its intellectual contribution, the "import substitution system" $\left(\mathrm{SSI}^{6}\right)$.

In fact, a discussion capable of sufficiently fueling another theoretical effort to understand the change in the connotation of Furtado's thought is, obviously, the issues of development, international division of labor, and imperialism, as Acosta and Brand (2019) achieve very well through the perspective of natural resources and new paths for socio-environmental development in Latin America. When analyzing the increasing dependence on extractive activities even under "progressive" governments, the authors question the fact that the current Latin American leaders are walking hand in hand with this model, embarking on what they call the "new developmental crusade," and they propose new understandings about the dignity of all beings and new practices - in addition to economic growth - to achieve it.

\section{WHAT DO CURRENTLY IS SAID ABOUT STRUCTURAL REFORMS?}

Structural reforms often accompany fiscal austerity programs in countries with debt problems and consist of an ambitious "big-bang” agenda: make as many changes as possible as quickly as possible (Bardaka et al., 2020; Rodrik, 2017). According to the authors, increasing the efficiency with which labor and capital are allocated to the economy, ensuring that these resources reach the place where their contribution to the national income is greatest, is nowadays reforms' main goal.

More diversified for the labor market, structural reforms are presented through the reduction of barriers to the entry of professionals, the reduction of the protection legislation and unemployment benefits, the elevation of the retirement age, the reduction of the opportunity cost for the maintenance of the labor force at retirement age, the raising of child support (daycare and maternity), and the implementation of active programs in the labor market that aim to facilitate the search for jobs. For the product market, the reforms aim to reduce regulations that harm the market's competitiveness and decrease the legal and administrative barriers to entrepreneurship as well as to international trade and investment (Anderson et al., 2014).

That said, the turnaround of the term is clear. These reforms, however, far from developmentalists but neoliberal, are much more inclined to the adjective "institutional" than "structural" due to the fact that their defenders are usually also new institutionalists ${ }^{7}$ : they defend the thesis that the economic development will take

\footnotetext{
${ }^{6}$ Sistema de Substituição de Importações.

${ }^{7}$ See Coase (1998).
} 
place in an optimal way, without any State intervention, as long as it acts to guarantee the smooth functioning of the market.

Although the reforms adopted by most OECD countries from the 1980s and 1990s aimed to combat the structure of social welfare at the expense of a neoliberal agenda, they differ considerably from what Furtado thought about the particular case of the Brazilian economy, in so that they should not be called by the same term. In addition, if in the developmentalist conception they had the objective of developing - not to say revolutionizing - periphery economies, the current literature still lacks consensus regarding the positive effect of the hereafter institutional reforms on the output and productivity of an economy in times of stagnancy (see Alesina et al. (2018) and Bouis et al. (2012) for favorable arguments; Bardaka et al. (2020) and Rodrik (2017) present less optimistic assessments).

Even when positive, the effect of the reforms regarding productivity and output, as found by studies focusing on the regional scope, such as those by Unni et al. (2001), for India, and Cardoso et al. (2020), for Brazil, can contribute to the regional concentration of productive activities and income - the contrary direction to the one that Furtado intended in his reform ideal.

\section{FINAL REMARKS}

The concept of structural reforms has changed considerably from Furtado to the present day. The external obstacles and internal solid factors, as highlighted by Furtado (1966), which lasted for decades in the country, certainly contributed to modifying the prospects for development guided by economic policy, limiting, to say the least, the possibilities that were once closer to revolutionary transformations in the social and economic spheres in Brazil.

For Furtado, the structural reforms - fiscal-administrative and agrarian, addressed in this article - sought to overcome the problems of underdevelopment intrinsic to the model of economic activity in the country, which led to the emergence of the developmentalist current in the mid-20th century, oriented toward economies of the "global south" in general. Today, subject to supporting policies of fiscal austerity packages in indebted economies, the achievement of reforms still lacks consensus in the literature.

The study aimed, above all, to emphasize the existence of a turning point in the theoretical framework on reforms that is barely perceived by the mainstream economic literature. It concludes that, in fact, for developing economies, the adjective "structural" should be addressed to the reforms of the developmentalist conception, a State-led strategy of economic development - a structural change itself. What is currently portrayed as reforms, therefore, should be accompanied by the adjective "institutional", since their current goals are influenced by the new-institutionalism, theory that sustains that the State should only guarantee the smooth functioning of the market.

As a result of the first challenge, the work also recognizes that the economic 
debate in Brazil has ceased to be, in the recent years, on relevant topics such as employment, growth and even less development, to deal almost exclusively with reforms. These, however, as I contextualized, can be identified and coordinated in different ways - each proposal has a set of policies behind it, a strategy, which, in the case of the current one, it sees the State as an obstacle to development, so that it needs to be systematically diminished by institutional reforms, through the implementation of new constitutional laws and amendments, since the Welfare State is actually foreseen in the Brazilian Federal Constitution.

The meaning of development seems, in practice, to have been forgotten, outdated or out scope of the mainstream, so that the deviation of certain concepts from their original references, as I also mentioned in the case of extractivism under socialdemocratic governments in Latin America, becomes increasingly common. This is possibly associated with the capitalist struggle to find ways of adapting to the current situation of developing countries, as Furtado's developmentalism brilliantly achieved in the mid-20th century, as well as in regard to the central economies.

The effort to rescue and understand the original conceptions of certain keywords in the economic development literature, as well as the way in which their interpretations and practices modify over time, as sought in this article regarding structural reforms, is shown to be of paramount importance for the constantly changing social debate in which the field of economic science participates.

\section{REFERENCES}

Acosta, Alberto, Ulrich Brand (2019) Pós-extrativismo e decrescimento: saídas do labirinto capitalista. Editora Elefante.

Alesina, Alberto, Carlo A. Favero, e Francesco Giavazzi (2018) "What do we know about the effects of austerity?", AEA Papers and Proceedings. Vol. 108. DOI: 10.1257/pandp.20181062.

Anderson, Derek, Benjamin Hunt, e Stephen Snudden (2014) "Fiscal consolidation in the euro area: How much pain can structural reforms ease?", Journal of Policy Modeling 36.5: 785-799. DOI: $10.1016 /$ j.jpolmod.2014.08.005

Annicchiarico, Barbara, Fabio Di Dio, e Francesco Felici (2013) "Structural reforms and the potential effects on the Italian economy”, Journal of Policy Modeling 35.1: 88-109. DOI: 10.1016/j.jpolmod.2012.03.002

Bardaka, Ioanna, Ioannis Bournakis, and Georgia Kaplanoglou (2020) “Total factor productivity (TFP) and fiscal consolidation: How harmful is austerity?”, Economic Modelling. DOI: 10.1016/j.econmod.2020.02.032

Bouis, R., Causa, O., Demmou, L., Duval, R., \& Zdzienicka, A. (2012). "The Short-Term Effects of Structural Reforms”, OECD Economics Department Working Papers. DOI: $10.1787 / 5 \mathrm{k} 9 \mathrm{cs}-$ vk4d56d-en

Cano, W. (2000). Celso Furtado e a questão regional no Brasil. Celso Furtado e o Brasil. São Paulo: Fundação Perseu Abramo, 93-120.

Cardoso, Guilherme, Thiago Simonato, Débora Cardoso, e Edson Domingues (2020) “Austeridade fiscal e reformas estruturais: quais seriam os ganhos de produtividade do trabalho necessários para compensar os impactos regionais contracionistas da agenda de austeridade?", Brazilian Regional Studies Association - Selected articles of the XVIII Enaber. (https://brsa.org.br/enaber2020/\#artigos) 
Coase, Ronald. (1998). The New Institutional Economics. The American Economic Review, 88(2), 7274. Retrieved January 12, 2021, from http://www.jstor.org/stable/116895

D’Araujo, Maria Celina (n.d.) O AI-5. Centro de Pesquisa e Documentação da História Contemporênea do Brasil, Fundação Getúlio Vargas. (https://cpdoc.fgv.br/producao/dossies/FatosImagens/ AI5)

Dweck, Esther, Ana Luíza Matos de Oliveira, e Pedro Rossi (2018) Austeridade e retrocesso: impactos sociais da política fiscal no Brasil. São Paulo: Brasil Debate e Fundação Friedrich Ebert. (https:// brasildebate.com.br/wp-content/uploads/DOC-AUSTERIDADE_doc3-_L9.pdf)

Ferreira, Afonso Henriques Borges; e Clélio Campolina Diniz (1995) "Convergência entre as rendas per capita estaduais no Brasil”, Brazilian Journal of Political Economy, v. 15, n. 4. (https://rep. org.br/rep/index.php/journal/article/view/1255)

Fonseca, Pedro C. Dutra (2015) “Desenvolvimentismo: a construção do conceito”, Ipea. Texto para Discussão. (http://repositorio.ipea.gov.br/bitstream/11058/4580/1/td_2103.pdf)

Furtado, Celso (1946) De Nápoles à Paris: Contos da vida expedicionário. Z. Valverde.

Furtado, Celso (1962) A pré-revolução brasileira. Rio de Janeiro: Fundo de Cultura.

Furtado, Celso (1964). Dialética do desenvolvimento (Vol. 2). Editora Fundo de Cultura.

Furtado, Celso (1966) Subdesenvolvimento e estagnação na América Latina. Rio de Janeiro: Civilização Brasileira.

Furtado, Celso (1968) Um projeto para o Brasil. Rio de Janeiro: Saga.

Furtado, Celso (1984). Cultura e desenvolvimento em época de crise (Vol. 80). Paz e Terra.

Furtado, Celso (1985). A fantasia organizada (Vol. 89). Rio de Janeiro: Paz e Terra.

Furtado, Celso (2020). Formação econômica do Brasil. Companhia das Letras.

Nicoletti, Giuseppe, and Stefano Scarpetta (2005) "Product market reforms and employment in OECD countries.” OECD Economics Department Working Papers. DOI: 10.1787/18151973

Nikiforos, Michalis, Dimitri B. Papadimitriou, and Gennaro Zezza (2015) "The Greek public debt problem”, Nova Economia 25.SPE: 777-802. DOI: 10.1590/0103-6351/3552

Rodrik, Dani. (2017) “The Elusive Promise of Structural Reform”, Political Economy Perspectives on the Greek Crisis. Palgrave Macmillan, Cham. 61-70. DOI: 10.1007/978-3-319-63706-8_3

Unni, Jeemol, N. Lalitha, and Uma Rani (2001) "Economic reforms and productivity trends in Indian manufacturing”, Economic and Political Weekly: 3914-3922. DOI: 10.2307/4411233 